\title{
ADHESIVE PROPERTIES OF AN OUTER STRUCTURE OF CLOSTRIDIUM PERFRINGENS TYPE A ISOLATED FROM PIGLETS WITH CATARRHAL ENTERITIS
}

\author{
Elizabeth Pelosi Teixeira ${ }^{1}$; Marlene Braide Serafim ${ }^{1}$; Maria Alice Cruz Höfling ${ }^{2}$; Aureo T.Yamada ${ }^{2}$; \\ Antonio Fernando Pestana de Castro ${ }^{3 *}$
}

${ }^{1}$ Departamento de Microbiologia e Imunologia and ${ }^{2}$ Laboratório de Microscopia Eletrônica, Instituto de

Biologia, Universidade Estadual de Campinas-UNICAMP, Campinas, SP, Brasil. ${ }^{3}$ Departamento de Microbiologia, Instituto de Ciências Biomédicas, Universidade de São Paulo-USP, São Paulo, SP, Brasil

\begin{abstract}
One strain (S32) of Clostridium perfringens type A was isolated from a case of catarrhal enteritis of piglets. This strain was able to adhere to HeLa cells showing an adherence index (AI) of $25.15 \pm 1.26$ (mean \pm 1 standard error of the mean). Treatment of the bacterial cells with trypsin $(0.25 \mathrm{mg} / \mathrm{ml})$ decreased in $70 \%-80 \%$ the AI and metaperiodate $(10 \mathrm{mg} / \mathrm{ml})$ abolished completely the adherence, suggesting that the structure responsible for this phenomenon was probably a glycoprotein. Heating of bacterial suspensions $\left(100^{\circ} \mathrm{C} / 5 \mathrm{~min}\right)$ before carrying out the adhesion test decreased the AI rendering it equal to the negative controls. Rabbit homologous S32 antiserum inhibited the adherence up to dilutions of 1: 640, at least. The piglet ileal loop assay, carried out with strains S32 and Jab-1 (negative control) demonstrated that the strain S32 was able to adhere to the intestinal epithelial cells when examined after Gram staining. Transmission electron microcopy (TEM) demonstrated that S32 strain displayed a loose fibrillar material not seen with Jab-1. Stabilization of the bacterial cells with homologous antiserum of strain S32, followed by staining with rhuteniun red, revealed loose long fibrillar material on the outer surface of the cells, that sometimes could be seen spreading out from the cells and linking bacterial cells. The question whether this structure might be an adhesin for this strain of $\mathrm{Cl}$. perfringes type A, perhaps playing a role in the pathogenesis of the catarrhal enteritis of piglets, is dependent on further studies.
\end{abstract}

Key words: $\mathrm{Cl}$. perfringens type A, adherence, fibrillar structure, enteritis, piglets

\section{INTRODUCTION}

Clostridium perfringens type A (CpA), besides causing food poisoning in man, has also been reported as responsible for either necrotic or catarrhal enteritis in piglets, calves, chickens and other animals $(7,8,9$, 21). The exact mechanisms, which could be involved in the early steps of both diseases, however remain obscure. CpA intestinal infection poses a crucial question: how does the microorganism adhere to the

\footnotetext{
* Corresponding author. Mailing address: Departamento de Microbiologia, Instituto de Ciências Biomédicas, USP, Cidade Universitária, CEP 05508-900, São Paulo, SP, Brasil. Fax: (+5511) 818-7354. E-mail: apestana@icb.usp.br
} 
intestinal epithelial cells of susceptible hosts? (4).

Whatever the disease to be considered it is feasible to assume that the vegetative bacterial cells must adhere to gut epithelial cells before going on with further mechanisms which are different for each enteropathogen $(6,12,13)$. So there are several reports in the literature on different structures that may act as colonization factors ( $\mathrm{CFs}$ ); putative colonization factors (PCFs); adhesin or adherence factors (AF) for other microorganisms $(4,10,11)$.

As far as adhesins of $\mathrm{CpA}$ are concerned, no reports have been found in the literature. Airbuckle (1) and Sims et al. (18) based upon histological findings of pigs and foals, which died from necrotic enteritis, suggested that $C l$. perfringens type $\mathrm{C}(\mathrm{CpC})$ was able to adhere to the intestinal cells of the diseased animals. More recently other workers have reported this adherence in vivo (2). Because $\mathrm{CpA}$ was isolated in pure culture from a piglet which died from catarrhal enteritis, the main purpose of this paper was to report the results of the experiments that have been undertaken in order to attempt the visualization of any external structure present on the surface of this bacterium, which could mediate the adherence of this isolate to the gut epithelial cells of its host, before triggering further mechanisms at the intestinal level.

\section{MATERIALS AND METHODS}

Bacterial strains and culture media. A pure culture of $\mathrm{CpA}$, strain S32, was isolated in our laboratory at the University of Campinas, SP, Brazil, from a piglet, which died from acute catarrhal enteritis. Prof. T. Yamagishi (Department of Microbiology, University of Toyama, Japan) made typing of this strain (20). Another Clostridium perfringens strain (Jab-1) (not typed) which did not produce either toxin $\beta$ or enterotoxin, isolated from the stools of a healthy piglet, was used as a negative control. The above bacterial strains were grown anaerobically (Gaspax System, BBL, Becton Dickinson, USA) on sulphide-polimyxinsulphadiazine (SPS) agar and Columbia Agar Base (Difco Lab. Detroit, USA) to which gentamycin $(40 \mu \mathrm{g} / \mathrm{ml})$ was added. Subcultures from isolated colonies were made in Brain Heart Infusion (BHI) and in Fluid Thioglycollate (FT) media at $37^{\circ} \mathrm{C}$ for $18 \mathrm{~h}$. BHI cultures were used for the experiments "in vitro" and "in vivo". Cultures were stored in FT medium at $8^{\circ} \mathrm{C}$.

\section{Adherence of Clostridium perfringens strains} to HeLa cells. The adherence assays of $\mathrm{Cl}$. perfringens strains S32 and Jab-1 to HeLa cells were carried out as described by Scaletsky et al. (17). For determination of the adhesion index, HeLa cells were first stained with Giemsa dye and thereafter examined under bright field microscopy using 320 magnification. Microscopic fields were chosen at random and the adhered bacteria were counted on $100 \mathrm{HeLa}$ cells. The mean $(\mathrm{x}) \pm \mathrm{SEM}$ (standard error of the mean) was calculated (5).

Influence of trypsin, metaperiodate and heat treatments of $\mathbf{C l}$. perfringens $\mathrm{S} 32$ bacterial cells on their adherence to HeLa cells. Trypsin $(0.25$ $\mathrm{mg} / \mathrm{ml}$ ) diluted in 0.05M HEPES mixed with saline plus $1 \mathrm{nM}$ Calcium Chloride, $\mathrm{pH} 7.6$ (stabilizer) was used. Briefly, $1.0 \mathrm{ml}$ of standardized bacterial suspension (tube 10 of Mac Farland's scale) of S32 - BHI cultures was mixed with $1.0 \mathrm{ml}$ of the enzyme and left at $37^{\circ} \mathrm{C}$ for $1 \mathrm{~h}$. Then, the trypsin-treated bacterial cells were washed $3 \mathrm{x}$ with $0.05 \mathrm{M}$ PBS, $\mathrm{pH}$ 7.4. Packed cells were resuspended in PBS to the original volume. Afterwards the adherence of this S32-trypsin treated bacteria were tested on monolayers of HeLa cells, as described above. In order to ascertain the effect of temperature on adherence of S32 strain of $\mathrm{Cl}$. perfringens, standard bacterial suspensions were heated to $100^{\circ} \mathrm{C}$ for $5 \mathrm{~min}$ and to $56^{\circ} \mathrm{C}$ for $10 \mathrm{~min}$ and then submitted to the adherence test to HeLa cells as described by Scaletsky et al. (17).

In order to verify whether periodate had any influence on the adherence of strain S32 to HeLa cells a similar protocol was set up. Thus, $1 \mathrm{ml}$ of 20 $\mathrm{nM}$ metaperiodate was mixed with an equal volume of standardized suspension of S32 bacterial cells. The mixture was incubated at $37^{\circ} \mathrm{C}$ for $30 \mathrm{~min}$ and then centrifuged and washed $3 \mathrm{x}$ with PBS 0.05M, pH 7.4. Packed cells were resuspended in this buffer and the adherence test to HeLa cells was performed as mentioned in the previous item. Appropriate controls represented by untreated standardized cultures were included in these experiments.

Preparation of S32 total antiserum. For the preparation of $\mathrm{Cl}$. perfringens $\mathrm{S} 32$ antiserum adult rabbits were immunized according to Batty and Walker (3), using for immunization or formalized bacterial whole cells treated bacterial whole cells grown in BHI medium. 
Inhibition of S-32 adherence to HeLa cells by homologous antiserum. Equivalent quantities $(0.5$ $\mathrm{ml}$ ) of packed bacterial cells from BHI S32 cultures, standardized to tube 10 of the Mac Farland's scale were mixed with the same amount of ten-fold dilutions of S32 antiserum. Mixtures were incubated for 30 minutes, at $37^{\circ} \mathrm{C}$ and thereafter centrifuged at $3,000 \mathrm{rpm}$ for $10 \mathrm{~min}$. Supernatants were discarded and the packed bacterial cells were harvested in $0.05 \mathrm{M}$ PBS, $\mathrm{pH} 7.4$, to the original volume $(1.0 \mathrm{ml})$. Afterwards, $0.1 \mathrm{ml}$ aliquots of the bacterium suspension were dropped on HeLa cell monolayers which grew on coverslips placed in a 24-well tissue culture plates (Falcon, USA), containing Eagle's medium plus $2 \%$ of fetal bovine serum (FBS).

The readings of the adherence tests were then performed as described above. All experiments were carried out in triplicate taking care to include negative control represented by Jab- $1 \mathrm{Cl}$. perfringens strain. Further assays were performed in the same day under equal conditions, without the addition of S32 antiserum. The inhibitory effect of serum treatment was evaluated by the comparison of the mean number (x) of S32 treated and non-treated adhered bacteria to HeLa cells \pm 1 SEM (standard error of the mean).

Piglet ileal loop assay. Landrace newborn female piglets (weighting $1 \mathrm{Kg}$ ?) were obtained from pregnant sows by Cesarean section carried out using all possible sterile precautions, so that the animals were considered "specific pathogen free" at least for up to $6 \mathrm{~h}$ after birth. As soon as possible after parturition the piglets were maintained in clean cages and submitted to laparatomy after being anesthetized by ether inhalation. Ileal region was sutured at the proximal and distal positions using sterile common thread. The whole ileal segment was then intraluminally injected with sterile PBS and after gentle manipulation downwards, all PBS was aspirated with a $20-\mathrm{ml}$ syringe and thereafter discarded. Fifteen $10 \mathrm{~cm}$-intestinal loops were thus made with double stitches $1 \mathrm{~cm}$ long, forming interloops separating each one from the adjacent loops.

Starting with the proximal loops, volumes of 0.5 $\mathrm{ml}$ of bacterial suspensions from strains $\mathrm{S} 32$ and Jab1 subcultured in $\mathrm{BHI}$ medium at $37^{\circ} \mathrm{C}$ for $18 \mathrm{~h}$, were injected into them at different positions of the gut. Further negative controls consisting of sterile saline and $\mathrm{BHI}$ medium at $37^{\circ} \mathrm{C}$ for $18 \mathrm{~h}$, were similarly injected into the remaining loops. After inoculation the intestines were replaced into the abdominal cavity and peritoneum, muscles and skin levels were stitched with cotton thread. Three hours after surgery the animals were euthanized and the intestines removed from the abdomen. The loops were excised and small tissue fragments of the gut loops were cut, fixed with formalin and prepared as described by Yamagishi et al. (20). The fragments were then embedded into paraffin and processed for histological examination. Sections $(5-6 \mu \mathrm{m})$ stained with hematoxilin-eosin were examined, using brightfield microscopy at 400x and 1000x magnification. Some sections were stained by Gram's procedure adapted to tissues according to Moulry and McManus (15) and then examined as described above.

\section{Transmission Electron Microscopy (TEM)} studies. For TEM studies, equal volumes $(100 \mu 1)$ of the $\mathrm{S} 32$ strain bacterial suspension from BHI cultures grown at $37^{\circ} \mathrm{C}$ for $18 \mathrm{~h}$ and $1 \%$ phosphotungstic acid solution were mixed. Aliquots of $10 \mu 1$ were dropped on 300-mesh copper grids covered with a supporting parlodium film where a carbon film had been previously applied. The samples were then negatively stained for 2-3 min. TEM studies were also performed on section of bacterial cells of the S32 and Jab-1 strains, which were grown in BHI medium at $37^{\circ} \mathrm{C}$ for $24 \mathrm{~h}$. Four $\mathrm{ml}$ of these cultures were centrifuged and washed 3 times with $0.05 \mathrm{M}$ PBS, $\mathrm{pH}$ 7.4. Thus, $0.15 \mathrm{ml}$ of undiluted $\mathrm{S} 32$ antiserum were mixed with either homologous or heterologous sedimented bacterial cells and left in contact at $37^{\circ} \mathrm{C}$ for $30 \mathrm{~min}$, with constant shaking. The mixtures were then centrifuged ( $3.000 \mathrm{rpm}$, for $15 \mathrm{~min}$ ) and the bacteria washed with distilled water. The same strains with no addition of S32 antiserum were used as controls.

Both controls and serum-treated bacterial cells were shared into two aliquots. One of each was fixed with $5 \%$ glutaraldehyde buffered with $0.2 \mathrm{ml}$ of $0.2 \mathrm{M}$ sodium cacodylate, $\mathrm{pH} 7.4$, for $30 \mathrm{~min}$. To the other, $0.15 \%$ of ruthenium red solution was added to the fixative. After another centrifugation, the pellets were fixed with $5 \%$ buffered glutaraldehyde plus $0.05 \%$ ruthenium red, overnight. The bacterial cells were then fixed with $2.5 \%$ glutaraldehyde. After being washed with the buffer, the cells were dehydrated throughout an acetone series $(30,50,70,90$, and $100 \%, 30$ min each). Ruthenium red $(0.05 \%)$ was also added to the bath with $30 \%$ and $50 \%$ acetone to 
prevent remotion of the dye from the bacterial cells. The material was embedded with the Epon 812 resin (14) and cut with glass knives on a Porter Blum MT2 ultramicrotome. The sections were double-stained with uranyl acetate and lead citrate (19) and observed on a Zeiss EM-9S2 transmission electron microscope, operated at $60 \mathrm{KV}$.

\section{RESULTS AND DISCUSSION}

The results obtained with the strain $\mathrm{S} 32$ of $\mathrm{Cl}$. perfringens submitted to the adherence test to $\mathrm{HeLa}$ cells showed that this strain had an adhesion index (AI) equal to $25.15 \pm 1.26(\mathrm{x} \pm 1 \mathrm{SEM})$ while the control strain JAB-1 showed an AI as low as $0.52 \pm$ 0.32 (data not shown). It was observed in this experiment that S32 strain was highly adherent to HeLa cells displaying themselves paralleled along the margins of the membranes of the HeLa cells (Fig. 1).

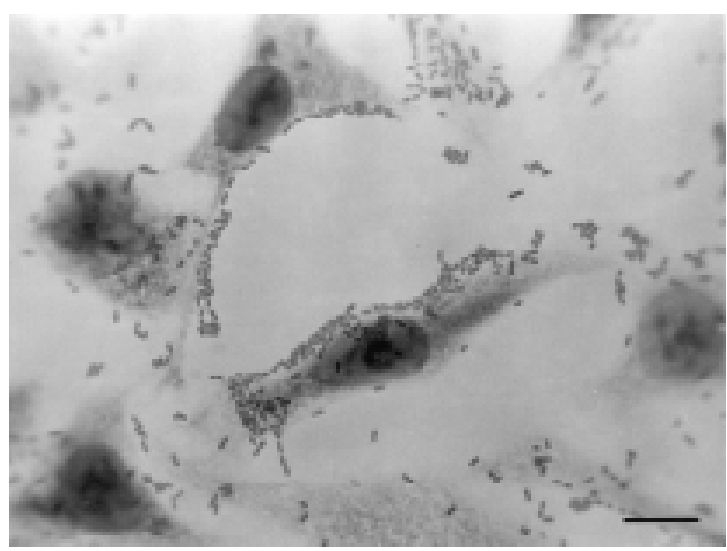

Figure1.Strain S32 of Clostridium perfringens adhered to HeLa cells. The parallel arrangement of the bacteria along the cellular membrane is easily observed. Magnification 1152 x. Bar (11mm) $=10 \mu \mathrm{m}$

As shown in Table 1 when the bacterial cells were treated with different concentrations of trypsin before the adherence test to HeLa cells, there was a marked decrease of the AI, around $70 \%-80 \%$. This finding suggested that at least part of the surface structure of S32 strain responsible for its adhesion to HeLa cells could be of protein nature.

In order to look for external structures of carbohydrate nature, strain $\mathrm{S} 32$ of Cl.perfringens was treated with different concentrations of metaperiodate which abolished significantly the adherence of this bacterium to HeLa cells (Table 1), suggesting that some type of glycoside was part of the adhesive structure. In other words, the surface structure of strain S32 responsible for HeLa adhesion, could be a glycoprotein.

With regard to the effect of temperature on adherence of strain S32 it was observed a decrease in the AI which was more pronounced with boiled bacterial cells (Table 1), similar to AI found for strain Jab-1. These data suggested that the biological activity of the structure responsible for the adhesion of strain S32 to HeLa cells was thermolabile, fitting with the hypothesis that this structure may be a glycoprotein.

Tests to look for the inhibition of the adherence of strain S32 to HeLa cells with homologous total antiserum (reciprocal tube agglutination titer equal to 320) were also performed. The results obtained are shown in Table 1 where an inhibition titer around 1:640 was observed. Higher dilutions of the antiserum did not interfere significantly in the process of adherence, though no adhesion index equal to the control $(25.15 \pm 1.78)$ was obtained anymore.

Table1.Influence of heating, homologous antiserum, metaperiodate and trypsin on the adherence of $\mathrm{Cl}$. perfringens S32 strain to HeLa cells.

\begin{tabular}{lc}
\hline Treatment $\begin{array}{c}\text { Adhesion index }(\mathrm{AI}) \text { to HeLa cells } \\
\text { (mean) } \pm \text { (standard error of the mean) } \\
\overline{\mathrm{X}} \pm(\mathrm{SEM})\end{array}$ \\
\hline None & $25.15 \pm 1.26$ \\
Heat $100 \mathrm{C}^{\mathrm{o}} / 5 \mathrm{~min}$ & $1.50 \pm 0.06$ \\
Heat $56^{\circ} \mathrm{C} / 10 \mathrm{~min}$ & $4.92 \pm 1.47$ \\
$\mathrm{~S} 32$ antiserum $(\mathrm{net})$ & $6.00 \pm 0.02$ \\
S32 antiserum $(1 / 10)$ & $9.93 \pm 0.56$ \\
S32 antiserum $(1 / 40)$ & $12.35 \pm 1.15$ \\
S32 antiserum $(1 / 160)$ & $15.65 \pm 1.36$ \\
S32 antiserum $(1 / 640)$ & $18.10 \pm 0.93$ \\
S32 antiserum $(1 / 2560)$ & $21.02 \pm 1.12$ \\
Trypsin $(0.25 \mathrm{mg} / \mathrm{ml})$ & $4.32 \pm 0.10$ \\
Metaperiodate $(10 \mathrm{mg} / \mathrm{ml})$ & $5.03 \pm 0.10$ \\
Metaperiodate $(5 \mathrm{mg} / \mathrm{ml})$ & $6.48 \pm 0.07$ \\
Metaperiodate $(2.5 \mathrm{mg} / \mathrm{ml})$ & $9.53 \pm 0.31$ \\
\hline
\end{tabular}

The piglet ileal loop assay using newborn animals demonstrated that $\mathrm{Cl}$. perfringens $\mathrm{S} 32$ strain was able to adhere to the intestinal epithelial cells. It is important to emphasize the fact that the short time (3h) used for the in vivo assays did not allow the production of several cytolytic toxins produced by this anaerobe which could affect the histological appearance of the gut epithelium. So, inoculation of 
strain S32 into the loops of the proximal, intermediary and distal intestinal regions of the small intestine did not show any histological lesions other than those seen with the loops inoculated with sterile BHI or the negative control (strain Jab-1) (data not shown).

When the histological sections were stained by the Gram's method only gram-positive bacteria could be seen stuck to the intestinal epithelium (Fig. 2) suggesting that these clusters were formed by the injected bacteria and that this result was not due to the quick colonization of normal flora of the gut. This phenomenon was reinforced by the findings of the controls injected into the loops with sterile saline or BHI, which showed at the same time no visible bacteria, neither attached to the epithelium lining nor to the gut lumen.

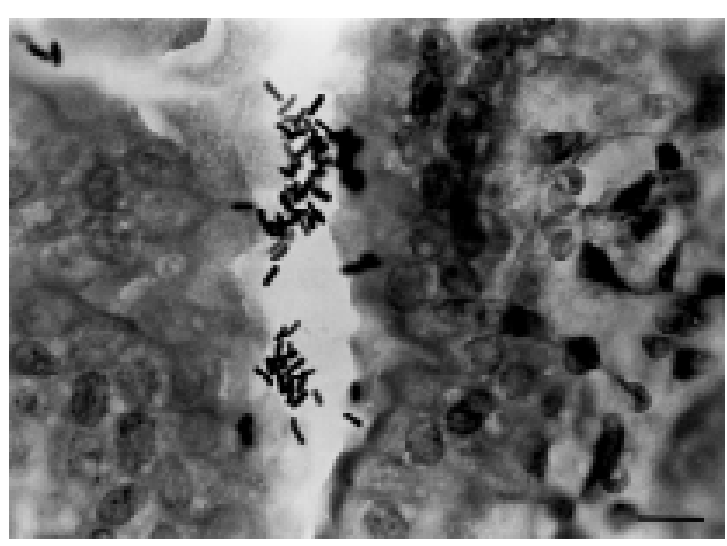

Figure 2.Transverse section of the small intestine of the piglet, after the inoculation of crude culture of strain S32 of Clostridium perfringens, into the distal position of the gut. Several bundles of the bacteria are seen adhered to the epithelium lining. Staining by H.E. Magnification 1024 x. Bar $(10 \mathrm{~mm})=10 \mu \mathrm{m}$

The in vivo tests carried out in this work are in agreement with histological studies performed by Arbuckle (1) in natural cases of necrotic enteritis observed in piglets. That author showed very clearly that the strains of $\mathrm{Cl}$. perfringens (type $\mathrm{C}$ ) were adhered to the intestinal villi of some sick animals, which were killed before being allowed dyeing from the disease. The report of one case of necrotic enteritis among foals was also studied similarly (18). These authors were also able to show several gram-positive bacteria adhered to gut villi of one animal, which had its intestine studied histologically. The electron microscopy studies by negative staining method tried to identify any structure of proteic nature on the bacterial surface of strain S32. At least 5 strains of $\mathrm{Cl}$. perfringens including Jab-1 were examined by this technique, as controls. All of them showed a "naked"appearance of their outer surface (data not shown). Strain S32, on the other hand, showed a very loose non-fimbrial structure (Fig. 3). Staining with ruthenium red, which is specific for the visualization of polysaccharide structures (glycocalix), was carried out with ultrathin sections. In this method we have also used the stabilization of possible outer surfaces, using for that purpose total S32 antiserum. Strain S32 so treated showed very clear fibrillar loose material extending in some cases from one bacterial cell to another and spreading out from the bacterial cells towards different directions (Fig. 4)

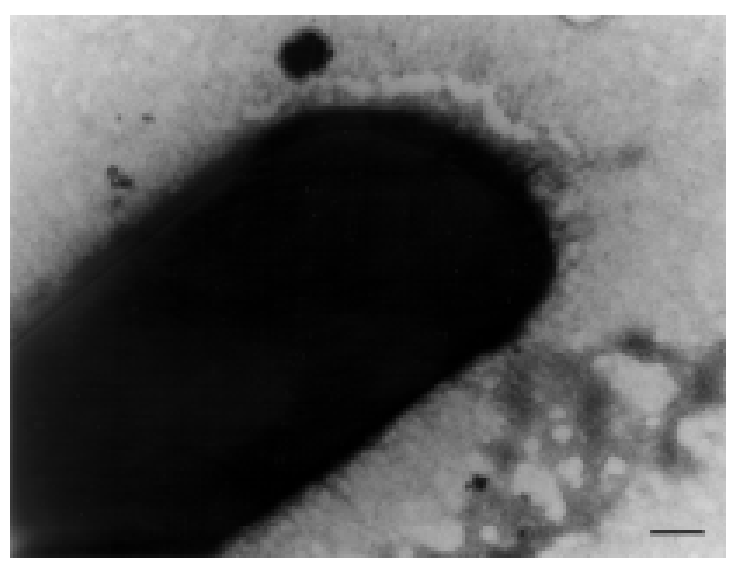

Figure 3. Strain $\mathrm{S} 32$ of Clostridium perfringens as seen by Transmission Electron Microscopy(TEM), negatively stained by $1 \%$ phosphotungstic acid. A loose structure is seen on the bacterial cell surface. Magnification 72,186 x. Bar $(8 \mathrm{~mm})=0.1 \mu \mathrm{m}$.

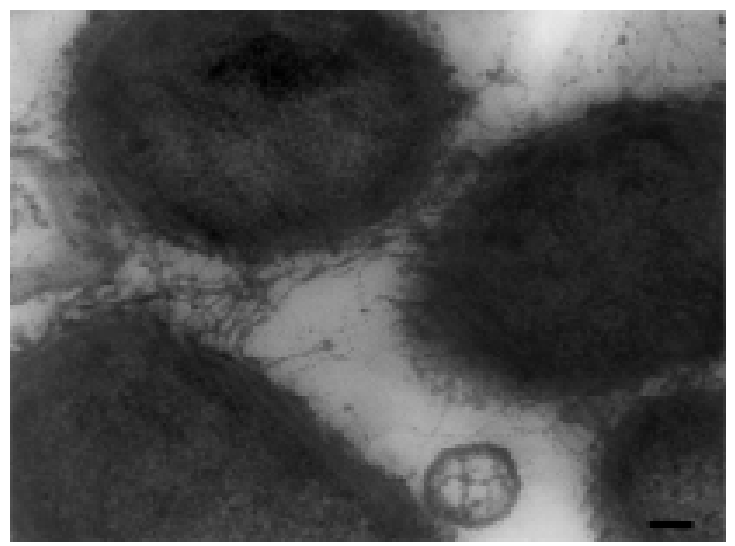

Figure 4. Ultrathin sections of the strain S32 of Clostridium perfringens after the stabilization of the outer structures by using homologous S32 antiserum and staining by ruthenium red which shows loose bundle around the bacteria, connecting some of them to each other. Magnification of 58,535x. $\operatorname{Bar}(6.5 \mathrm{~mm})=0.25 \mu \mathrm{m}$. 
We are not aware of any report on $\mathrm{Cl}$. perfringens colonization factors. Our data suggest that with this bacterium, when the site of infection is the gut, an initial obligate stage represented by adhesion of bacterial cells to the villi does occur. Whether the structure is always similar to that observed in strain $\mathrm{S} 32$ with regard to other strains of $\mathrm{Cl}$. perfringens remains to be further studied.

We were lucky to come across strain $\mathrm{S} 32$ of $\mathrm{Cl}$. perfringens, which showed some kind of very tiny structure, even when examined by transmission electron microscopy, using the negative staining technique. This technique was efficient only with this strain and allowed in vitro and in vivo tests and has permitted us to go further with more detail in the adhesion tests to HeLa cells. We finished with the surface structure stabilization by total homologous antiserum complemented with staining with ruthenium red. The results obtained support the glycocongugates nature of the surface structure of strain $\mathrm{S} 32$ responsible for its adhesive properties. As far as we know, after the first papers on in vivo adherence by $\mathrm{Cl}$. perfringens $(1,16,18)$ this is so far the first report to demonstrate that in vivo and in vitro adherence occurs with this strain of $\mathrm{Cl}$. perfringens, whose adhesive properties may imply that they could play a putative role in the catarrhal enteritis of piglets caused by this strains of $\mathrm{Cl}$. perfringens.

\section{ACKNOWLEDGEMENTS}

To Prof. Dr. Paulo Pinto Joazeiro, from the Microscopy Center, Institute of Biology, University of Campinas, SP, Brazil, for taking the light and electrom microscope photographs This work has received financial support from "Fundação de Amparo à Pesquisa do Estado de São Paulo (FAPESP)" and "Conselho Nacional de Pesquisa e Desenvolvimento Tecnológico (CNPq)", Brazil

\section{RESUMO}

\section{Propriedades adesivas de uma estrutura externa de Clostridium perfringens tipo A isolada de leitões com enterite catarral}

Uma amostra (S32) de Clostridium perfringens tipo A foi isolada de um caso de enterite catarral em leitões. Esta amostra foi capaz de aderir a células HeLa mostrando um índice de adesão (AI) de 25,15 $\pm 1,26$ (media \pm 1 erro padrão da media). Tratamento das células bacterianas com tripsina $(0,25 \mathrm{mg} / \mathrm{ml})$ diminuiu $70 \%-80 \%$ e metaperiodato $(10 \mathrm{mg} / \mathrm{ml})$ aboliu significantemente a adesão, sugerindo que a estrutura responsável por esta adesão era provavelmente uma glicoproteína. $\mathrm{O}$ tratamento pelo calor das suspensões bacterianas $\left(100^{\circ} \mathrm{C} / 5 \mathrm{~min}\right)$ diminuiu o $\mathrm{AI}$ ao nível dos controles negativos. Soro de coelho anti-S32 inibiu a aderência a células HeLa até a diluição de 1:640, pelo menos. O teste da alça ligada de leitão recem nascido demonstrou que a amostra S32 era capaz de aderir às células epiteliais intestinais, conforme demonstrado pela coloração de Gram de seç̧ões histológicas do intestino dos animais inoculados. $\mathrm{O}$ estudo em Microscópio Eletrônico de Transmissão demonstrou que a amostra $\mathrm{S} 32$ de $\mathrm{Cl}$. perfringens mostrava um material de natureza fibrilar frouxa, ao contrário da amostra Jab-1 (controle negativo) que demonstrava uma aparência "nua ou lisa". A estabilização das células bacterianas com antissoro homólogo (S32), seguida de coloração com vermelho de rutenio, revelou de maneira mais nítida que longos materiais fibrilares, de aparência frouxa, se estendendo para longe da célula bacteriana, ligando por vezes estas células entre si. A possibilidade desta estrutura ser uma adesina para esta amostra de $\mathrm{Cl}$. perfringens tipo A, talvez desempenhando um papel na patogenia da enterite catarral de leitões, depende de mais estudos.

Palavras-chave: $\mathrm{Cl}$. perfringens tipo A, aderência, estrutura fibrilar, enterite, leitões.

\section{REFERENCES}

1. Arbuckle,J.B.R. The attachment of Clostridium welchii $(\mathrm{Cl}$ perfringens) type $\mathrm{C}$ to the intestinal villi of pigs. J. Pathol. 106:65-72, 1972.

2. Baba, E.; Tsukamoto, Y.; Sasai, K.; Arakawa, A. Increase of mannose residues, as Salmonella typhimurium -adhering factor, on the mucosa of germ-free chickens infected with Eimeria tenella. Amer. J. vet. Res. 54: 1471-1475,1993.

3. Batty, I.; Walker,P.D. Differentiation of Clostridium septicum and Clostridium chauvoei by the use of fluorescent labeled antibodies. J. Path.Bact. 85:517-521,1963.

4. Beachey,E.H. Bacterial adherence: adhesin-receptor interactions mediating the attachment of bacteria to mucosal surfaces. J. Food Hyg. Soc. 20:33-40, 1981

5. Bishop,O.N. Statistics for Biology, Longmans, Edinburgh, Great Britain $1^{\text {st }}$ Ed. 1966, 188p.

6. Brooker, B. E.; Fuller, R. Adhesion of Lactobacilli to the chicken crop epithelium. J.Ultraestr. Res. 52:21-311975.

7. Carter,G.R.; Chengappa, M.M.; Roberts. A.W. Essentials of Veterinary Microbiology.Williams \& Wilkins. $5^{\text {th }}$ Ed.,1995, $394 \mathrm{p}$. 
8. Daube, G.; Simon, P.; Limbourg, B.; Manteca, C.; Mainil, J.; Kaeckenbeeck, A. Hybridization of 2,659 Clostridium perfringens isolates with gene probes for seven toxins (alpha, beta, epsilon, iota, theta, mu and enterotoxin) and for sialidase. Amer. J. vet. Res. 57: 496-501, 1996.

9. East, L.M.; Savage, C.J.; Traub-Dargatz, J.L.; Dickinson, C. E.; Ellis, R. P. Enterocolitis associated with Clostridium perfringens infection in neonatal foals: 54 cases (1988-1997). J. Amer. Vet. Med. Assoc. 212: 1751-1756, 1998.

10. Fuller,R. Nature of the determinant responsible for the adhesion of lactobacilli to chicken crop epithelial cell. J. Gen. Microbiol. 87:245-250. 1975.

11. Imberechts,H.; De Greve, H.; Lintermans, P. The pathogenesis of edema disease in pigs. A review. Vet. Microbiol. 31:221233, 1992

12. Jones,G.; Rutter, J. M. Role of the K88 antigens in the pathogenesis of neonatal diarrhoea caused by Escherichia coli in piglets. Infect.Immun., 6:918-927, 1972

13. Jones,G.W. The attachment of bacteria to the surfaces of animal cells. In: Microbial Interactions (Reissig, J.L., Editor) Receptor and Recognition, Series B, vol 6, p 141,Chapman and Hall, London, 1977.

14. Luft, J.H. Improvements in epoxy resin embedding methods. J. Bioph. Biochem. Cytol. 9:409-414, 1961.
15. Moulry, R. W.; McManus, I.F.A., Staining Methods Histological and Histochemical. A Holber International Reprint. ${ }^{\text {st }}$ Ed. p362-364,1964

16. Pearson, E. G.; Hedstrom, O. R.; Sonn, R.; Wedman, J. Hemorrhagic enteritis caused by Clostridium perfringens type C in a foal. J. Amer. Vet. Med. Assoc. 188: 1309-1310, 1986.

17. Scaletsky, I.C.A.; Silva, M.L.M.; Trabulsi,L.R. Distinctive patterns of adherence of enteropathogenic Escherichia coli to HeLa cells. Infect. Immun. 42:534-536, 1984.

18. Sims, L.; D., Tzipori,S.; Hazard,G. H.; Carrol,C. L. Haemorrhagic necrotizing enteritis in foals associated with Clostridium perfringens. Austr.Vet. J. 62:194-196, 1985.

19. Venable, J. H.; Coggeshall, R. A simplified lead citrate stain for use in electron microscopy with heavy metals. J.Cell Biol. 25:407-408, 1965.

20. Yamagishi,T., Gyobre, Y., Sakamoto,K., Ishisaka,S., Saito,K., Morinaga,S.; Katsuda,S.; Unei,T.; Konishi,T. Response of ligated rabbit ileal loop to Clostridium perfringens type C strains. Microbiol. Immunol. 31:859-868, 1987.

21. Yoo, H.S.; Lee, S.V.; Park, K.Y.; Park, I.H. Molecular typing and epidemiological survey of prevalence of Clostridium perfringens types by PCR. J. Clin. Microbiol.35:228-232, 1997. 